\title{
SPORTIVE
}

https://dergipark.org.tr/tr/pub/sportive

\section{Orta Ergenlik Dönemindeki Bireylerin Boş Zaman Faaliyetlerine Katılımlarına Engel Olabilecek Unsurların Belirlenmesi}

\author{
Lukman ÖNEN
}

Konya İl Milli Eğitim Müdürlüğü , Konya/Turkey

\begin{tabular}{lll}
\hline Orijinal Makale & Gönderi Tarihi:08.06.2021 & Kabul Tarihi:30.08.2021 \\
\hline
\end{tabular}

$\mathrm{Bu}$ araştırmada, orta ergenlik dönemindeki bireylerin boş zaman faaliyetlerine katılımına engel olabilecek etkenlerin incelenmesi amaçlanmıştır. Araştırmaya, liselerde öğrenim gören orta ergenlik dönemindeki 14-17 yaş arası 243'ü erkek, 210'u kadın toplamda 453 birey katılmıştır.Veri toplama aracı olarak Alexandris ve Carrol (1997) tarafından geliştirilen, Gürbüz ve diğerleri (2012) tarafından revize edilen 18 madde ve 6 alt boyuttan oluşan "Boş Zaman Engelleri" ölçeğinden faydalanılmıştır. Elde edilen veriler, SPSS 21 paket programı kullanılarak analiz edilmiştir. Araştırmada verilerin yüzde ve frekans değerleri alındıktan sonra parametrik testlerden Bağımsız Örneklem T-Testi ve ANOVA testi uygulanmıştır. Anlam düzeyi olarak 0.05 değeri alınmıştır. Bu çalışmada elde edilen bulgu ve analizlere göre, orta ergenlik dönemindeki bireylerin rekreatif etkinliklere katılımını etkileyen faktörlerde yaş değişkenine göre istatiksel yönden bir farklılığın olmadığı görülmektedir. "Cinsiyet" ve "Sınıf düzeyi" değişkenlerine bakıldığında ise "arkadaş eksikliği", "bilgi eksikliği", "tesis" ile "birey psikolojisi” alt boyutlarında istatistiksel yönden anlamlı bir farklılık saptanmıştır ( $\mathrm{p}<0.05)$.

Keywords: Orta ergenlik, rekreasyon, boş zaman engelleri

\section{Determination of Elements that May Prevent Middle Adolescents from Participating in Leisure Activities}

In this study, it was aimed to examine the factors that may prevent individuals in midadolescence from participating in leisure activities. A total of 453 individuals, 243 males and 210 females, aged 14-17, in middle adolescence, studying at high schools, participated in the study. As a data collection tool, the "Leisure Time Barriers" scale consisting of 18 items and 6 sub-dimensions, developed by Alexandris and Carrol (1997) and revised by Gürbüz et al. The obtained data were analyzed using the SPSS 21 package program. After obtaining the percentage and frequency values of the data in the study, the Independent Sample T-Test and ANOVA test, which are parametric tests, were applied. A value of 0.05 was taken as the significance level. According to the findings and analyzes obtained in this study, it is seen that there is no statistical difference according to the age variable in the factors affecting the participation of individuals in the middle adolescence period in recreational activities. When the "Gender" and "Class Level" variables were examined, a statistically significant difference was found in the "lack of friends", "lack of knowledge", "facility" and "individual psychology" sub-dimensions $(\mathrm{p}<0.05)$.

Keywords: Mid- adolescence, recreation, leisure barrier 


\section{GİRIŞ}

İnsanoğlu varoluşundan bu yana meşguliyet içerisindedir. Fizyolojik ihtiyaçlarını karşılamak için verdiği uğraş, iş hayatında yaşamış olduğu yoğunluk, bilgi birikimini artırıma çabaları ve ebeveynlik gibi uğraşlar insan yaşamını monoton bir hale getirmektedir. Bu süreçler, kendine vakit ayırmadan tekdüze bir yaşam sürer hale gelmiş insanı makineleşmeye zorlamıştır. Nasıl makinelerin daha iyi verim vermesi için yağlanmaya ihtiyacı varsa bireyler içinde boş zamanlar öyledir. Yani, boş zaman bireylerin fiziksel ve zihinsel olarak yenilendiği ve kendisine zaman ayırdığı çok önemli bir zaman dilimidir. Bireylerin, hayatın monotonluğundan ve karmaşasından uzaklaşmak için kendine zaman ayırması modern çağda boş zaman kavramının önemini gündeme getirmiştir.

Boş zaman; bireyin kendine ayırdığı vakitte kendi hür iradesi ile seçeceği bir faaliyetle uğraştığı zamandır (Bakır, 1990). Bulunduğumuz zaman diliminde, tüm yaş grupları için değişik açılardan mühim olan boş zaman kavramının iyi değerlendirilmesi farklı bir deyişle verimli kullanılması kritik bir öneme sahiptir. Bireylerin zamanlarını olumlu, verimli ve etkin kullanabilmeleri yaşantılarına olumlu etki eden bir durumdur. İş ve sosyal yaşantılarında zaman planlamasını iyi yapması gereken bireylerde iş ve sosyal yaşantıları arasındaki dengesizlik birçok olumsuz sonuçlar doğurabilir. Bu yönde bireylerin iş ve sosyal yaşantılarında boş zamanlarını verimli değerlendirmeleri son derece mühimdir (Akkaşoğlu ve Akyol, 2020).

Rekreasyonu, 'Boş zamanı değerlendirme gayesiyle yapılan etkinliklerin bütünü' biçiminde ifade edebiliriz (Türkay vd., 2015). Rekreasyon, boş zamanda icra edilen, bireyin bedenini ve ruhunu tazeleyen, sosyal yönden onaylanmış, gönüllülük ilkesine bağll aktiviteler bütünüdür (Orel ve Yavuz, 2003). Bireylerin boş vakitlerinde katıldıkları rekreasyon aktiviteleri yaşantılarına olumlu katkılar sağlamaktadır. Boş zaman faaliyetlerine katılım gösterme, bilhassa genç bireylerin sosyal ve bilişsel gelişimlerine katkı sağlayan bir husustur. Aynı zamanda bu etkinlikler, bireylerin fiziksel ve zihinsel gelişimlerine olumlu katkılar sağlamaktadır (Dinç vd., 2018). Diğer taraftan bu faaliyetler bazı zamanlarda katılım engelleri oluşturabilmektedir (Bulut ve Koçak, 2016). Özellikle ergenlik döneminde bulunan bireylerin eğitilmesi, fiziksel olarak geliştirilmesi ve de sağlıklı toplumların oluşması açısından fiziksel rekreatif aktiviteler hayati önem taşımaktadır (Uzun ve Boyalı, 2020).

Ergenlik; fizyolojik, psikolojik ve sosyal yönden olgunlaşmanın gerçekleştiği, çocukluktan yetişkinliğe geçiş sürecidir. Bu süreç, fizyolojik, psikolojik ve sosyal yönden değişimler ile ayırt edici özelliktedir (Parlaz vd., 2012). Dünya Sağllk Örgütü (WHO), "ergenliğin" bireyin hayatında sabit bir zaman diliminden ziyade bir evre olduğunu açıkça kabul etmektedir. WHO, ergenleri 10-19 yaş grubundaki bireyler olarak, orta ergenleri ise 14-17 yaş grubundaki bireyler olarak tanımlamaktadır 
(WHO, 2021). Orta ergenlik dönemi; fiziksel değişimin yoğun olduğu, soyut düşünme döneminin başladığı, bugün ve gelecek arasında bağların kurulmaya başladığı çok önemli bir dönemdir (Yavaş, 2012). Bu dönemde bulunan bireylerin boş zaman faaliyetlerine katılım göstermeleri, sosyal, fiziksel ve zihinsel gelişimlerine olumlu katkılar sağlamaktadır (Dinç vd., 2018). Fiziksel rekreatif faaliyetler, orta ergenlik döneminde bulunan 14-17 yaş grubundaki bireylerin eğitilmesi, fiziksel olarak geliştirilmesi ve sağlıklı toplumların oluşması açısından oldukça önemli bir role sahiptir (Uzun ve Boyalı, 2020). Yapılan araştırmalarda, rekreatif faaliyet olarak fiziksel aktiviteleri seçen orta ergenlik dönemindeki bireylerin düzenli spor yapma alışkanlıklarının sağlıklı olmadığı görülmektedir. Bu yaş grubunda rekreatif faaliyetlere özellikle spora katılım oranlarının düşük olduğu bilinmektedir. Yaş ortalaması 15,34 olan 357 orta ergenlik dönemindeki bireylerde yapılan çalışmada, bu bireylerin sadece \%49,7 sinin düzenli spor aktivitesine katıldığı görülmektedir (Akman vd., 2012). Dünya Sağlık Örgütü (WHO), çocuklar ve ergenler için fiziksel aktivite olarak, aile,okul ve toplum aktiviteleri bağlamında oyun, spor, ulaşım, ev işleri, beden eğitimi veya planlı egzersizi kabul edilebileceğini belirtmiştir (Uzun ve Boyall, 2020). Bireyin sosyal, fiziksel, zihinsel ve duygusal gelişim aşamalarına olumlu etki eden bu tür faaliyetler bazı zamanlarda katılım engelleri de oluş̧urabilmektedir (Bulut ve Koçak, 2016).

Günümüzde yapılan birçok araştırmanın bulgularına göre, bireylerin boş zamanlarını genellikle pasif faaliyetlere katılım göstererek veya hiçbir faaliyete katılım göstermeyerek geçirdikleri görülmüş̧ür (Temir ve Gürbüz, 2012). Bireylerin, boş zaman faaliyetlerine katılımlarına etki eden çeşitli etkenler bulunmaktadır. Bu etkenlerin boş zaman tercihleri üzerine etkileri de bireyden bireye farklılık sergilemektedir. Boş zaman engelleri, bireyin boş zaman faaliyetlerine katılımını engelleyen, ya da katılımılla alakalı pozitif hisleri tüketen etkenlerin bütünü olarak ifade edilmektedir (Kaas, 2016). Yapılan bu araştırma, orta ergenlik dönemindeki öğrencilerin rekreatif faaliyetlere katılımlarında karşılaştıkları engelleri saptamaya yöneliktir. $\mathrm{Bu}$ çerçevede, orta ergenlik dönemindeki öğrencilerin rekreatif faaliyetlere katılımlarında karşılaştıkları engeller nelerdir? sorusuna yanıt aranılıp; bu engellerin bazı bağımsız değişkenlere göre farklılaşıp farklılaşmadığı saptanmaya çalışılmıştır. Ayrıca ele alınan bağımsız değişkenlerin, bireylerin rekreatif faaliyetlerine katılımlarını etkileyip etkilemediğini inceleyen birçok bilimsel araştırmanın yanında bu araştırmanın da alan yazına katkı sağlaması beklenmektedir.

\section{YÖNTEM}

$\mathrm{Bu}$ çalışmada, betimsel araştırma yöntemlerinden tarama modeli uygulanmıştır. Araştırmanın bu kısmında, araştırma grubu, veri toplama araçları ve veri toplama analizi ile ilgili bilgiler yer almıştır. 


\section{Araştırma Yayın Etiği}

Araştırma için, Necmettin Erbakan Üniversitesi Etik Kurulu'nun 16/04/2021 tarih ve 2021/290 sayılı kararı ile araştırmanın etik uygunluk onayı alınmıştır.

\section{Araştırma Grubu}

Araştırmaya, liselerde öğrenim gören ve uygun örnekleme modeli ile belirlenmiş orta ergenlik dönemindeki 14-17 yaş arası 243'ü erkek, 210'u kadın toplamda 453 öğrenci dahil edilmiştir. Gerekli yetkili mercilerden izin alındıktan sonra anket uygulamasına geçilmiştir. Anket öncesi, katılımcılara araştırmanın amacı ve içeriğiyle alakalı bilgiler verilmiştir.

\section{Veri Toplama Araçları}

Covid-19 süreci nedeniyle veri toplama aracı olarak çevrim içi anket yönteminden faydalanılmıştır. Çalışmada faydalanılan veri toplama aracı 2 kısım olarak düzenlenmiştir. İlk kısımda, katılımcılarının demografik bilgilerini tanımlamaya dair sorular, ikinci kısımda ise Alexandris ve Carrol (1997) tarafından geliştirilen (Alexandris \& Carroll, 1997), Gürbüz ve diğerleri (2020) tarafından revize edilen 18 madde ve 6 alt boyuttan oluşan "Boş Zaman Engelleri” ölçeği araştırmamızda kullanılmıştır (Gürbüz vd., 2020). Ölçek, bireyleri Boş Zaman Engellerini belirlemeye yönelten, [1] "zaman ve ilgi eksikliği", [2] "birey psikolojisi", [3] "bilgi eksikliği”, [4] "ulaşım sorunu", [5] "tesis yetersizliği”" ve [6] "arkadaş eksikliği’"gibi 6 alt boyut ve ölçmeye yönelik 18 maddeden oluşmaktadır. Bireylerin Boş Zaman Engelleri, "Kesinlikle Önemsiz [1]", "Önemsiz [2]", "Önemli [3]", ve "Çok Önemli [4]" şeklinde 4'lü likert tipi ölçek üzerinde değerlendirilmektedir. Yapılan bu çalışmada elde edilen veriler üzerinde hesaplanan Cronbach Alpha güvenirlik katsayısı tüm maddeler için $=.793$ olarak hesaplanmıştır.

\section{Verilerin Analizi}

Araştırmaya, liselerde öğrenim gören orta ergenlik dönemindeki 14-17 yaş arası 243'ü erkek, 210'u bayan toplamda 453 birey katılmıştır. 453 adet çevrim içi anketten eksik veya hatalı veri tespit edilmemiştir. Toplamda 453 çevrim içi anket değerlendirmeye alınmıştır. Anketler IBM SPSS 21 istatistik programına aktarılıp gerekli kodlamalar yapılmıştır. Elde edilen verilerin analizinden önce ilk olarak verilerin normal dağılıma uygunluğu incelenmiş, diğer bir deyişle verilerin parametrik koşulları sağlayıp sağlamadığı incelenmiştir. Normal dağılıma uygunluk, skewness-kurtosis değerlerine bakılarak değerlendirilmiştir. Çarpıklık değerinin \pm 2 aralığında olması (George \& Mallery, 2010), basıklık değerinin ise \pm 2 (George \& Mallery, 2010) değerinden daha küçük olması normal dağılım koşullarını sağlaması yönünden yeterli görülmektedir. Skewness-kurtosis değerleri normal dağılım varsayımının karşılanması için yeterli puan aralığındadır. Bu nedenle çalışmanın 
farklılık testlerinde parametrik test teknikleri kullanılmıştır. İki bağımsız değişken için T testi, ikiden fazla bağımsız değişken için ise tek yönlü varyans analizi (Anova) testi uygulanmıştır. Anova'da çoklu karşılaştırmalar için post hoch testlerinden scheffe testi uygulanmıştır. Ölçeğin güvenilirlik sonuçları cronbach alpha ile değerlendirilmiştir.

\section{BULGULAR}

Katılımcıların demografik özelliklerinin yer aldığı Tablo 1'de araştırmaya dahil olan orta ergenlik dönemindeki öğrencilerin sınıf düzeyi, cinsiyet ve yaş değişkenleri ile ilgili bilgiler yer almaktadır.

Tablo 1: Demografik Özellikler

\begin{tabular}{lrc}
\hline Cinsiyet & $\mathbf{n}$ & $\mathbf{\%}$ \\
\hline Kadın & 210 & 46,4 \\
Erkek & 243 & 53,6 \\
Toplam & $\mathbf{4 5 3}$ & $\mathbf{1 0 0}$ \\
Yaş & $\mathbf{n}$ & $\mathbf{\%}$ \\
14 & 82 & 18,1 \\
15 & 131 & 28,9 \\
16 & 116 & 25,6 \\
17 & 124 & 27,4 \\
Toplam & $\mathbf{4 5 3}$ & $\mathbf{1 0 0}$ \\
Sinıf_Düzeyiniz & $\mathbf{n}$ & $\mathbf{\%}$ \\
9. Sinıf & 204 & 45,0 \\
10. Sinıf & 113 & 24,9 \\
11. Sinıf & 95 & 21,0 \\
12. Sinıf & 41 & 9,1 \\
\hline Toplam & $\mathbf{4 5 3}$ & $\mathbf{1 0 0}$ \\
\hline
\end{tabular}

Araştırmaya katılan katılımcıların demografik özellikleri Tablo 1'de gösterilmiştir. $\mathrm{Bu}$ verilere göre araştırmaya katılan katılımcıların \%46,4'ünün kadın, \%53,6'sının ise orta ergenlik dönemindeki erkek katılımcılardan oluştuğu görülmektedir. Aynı zamanda araştırmaya dahil olan toplam 453 öğrencinin \%46,4'ü eğitimlerini 9. sinıfta, \%24,9'u 10. sinifta, \%21'i 11.sinıfta, \%9,1'i ise 12 . sinıfta sürdürmektedirler. Bu öğrencilerin \%100'ü devlet okullarında eğitimlerini sürdürmektedir.

Tablo 2. Araştırma Değişkenlerine İlişkin Tanımlayıcı İstatistik Değerleri

\begin{tabular}{llllll}
\hline Değişkenler & $\mathbf{n}$ & $\mathbf{x}$ & s.s. & Skewness & Kurtosis \\
\hline Cinsiyetiniz & 453 & 1,54 &, 499 &,- 147 & $-1,987$ \\
Yaşınız & 453 & 2,62 & 1,071 &,- 093 & $-1,253$ \\
\hline Sinıf Düzeyiniz & 453 & 1,94 & 1,010 &, 650 &,- 832 \\
\hline
\end{tabular}


Tablo 2`de normallik dağılımı sonuçlarına ilişkin sonuçlara yer verilmiştir. Yapılan normal testinde verilerin normal dağılım göstermediği tespit edilmiştir. Ancak çarpıklık ve basıklık değerlerinin -2 ile +2 arası değerler alması verilerin normal dağılım şartlarını sağladığını göstermektedir (George \& Mallery, 2010).

Tablo 3. Araştırmada Serbest Zaman Engellerinin Cinsiyet Değişkeni Açısından Karşılaştırılması

\begin{tabular}{lllllll}
\hline Alt Faktörler & Cinsiyet & $\mathbf{n}$ & $\mathbf{x}$ & $\mathbf{s s}$ & $\mathbf{t}$ & $\mathbf{p}$ \\
\hline Ölçek Toplam & Kadın & 210 & 2,9794 &, 33728 & 3,436 & $\mathbf{0 0 1}$ \\
& Erkek & 243 & 2,8578 &, 41531 & & \\
\hline Birey psikolojisi & Kadın & 210 & 2,8873 &, 50146 & 2,297 & $\mathbf{0 2 0}$ \\
& Erkek & 243 & 2,7668 &, 60038 & & \\
\hline Bilgi eksikliği & Kadın & 210 & 3,2365 &, 58752 & 2,594 & $\mathbf{0 1 0}$ \\
& Erkek & 243 & 3,0878 &, 63171 & & \\
\hline Tesis & Kadın & 210 & 3,1111 &, 58905 & 2,120 &, $\mathbf{0 3 5}$ \\
& Erkek & 243 & 2,9877 &, 64235 & & \\
\hline Arkadaş eksikliği & Kadın & 210 & 2,7905 &, 71105 & 2,837 & $\mathbf{0 0 5}$ \\
& Erkek & 243 & 2,5981 &, 72718 & & \\
\hline Zaman & Kadın & 210 & 3,0587 &, 56501 & 1,632 &, 103 \\
& Erkek & 243 & 2,9684 &, 60561 & & \\
\hline Illgi eksikliği & Kadın & 210 & 2,7921 &, 59113 &, 951 &, 342 \\
& Erkek & 243 & 2,7380 &, 61392 & & \\
\hline
\end{tabular}

Tablo 3`e göre araştırma ölçeği ve alt faktörlerinin cinsiyet değişkenine göre karşılaştırılması sonucunda anlamlı farklılıklara rastlanmıştır $(\mathrm{p}<0,05)$. Boş zaman engelleri ölçeği alt boyutlarının cinsiyet değişkenine göre analiz sonuçları incelendiğinde, "arkadaş eksikliği" ( $\mathrm{t}=2,837 ; \mathrm{p}<0.05)$, "tesis" $(\mathrm{t}=2,120 ; \mathrm{p}<0.05)$, "bilgi eksikliğì" ( $\mathrm{t}=2,594 ; \mathrm{p}<0.05)$ ve "birey psikolojisi”" $(\mathrm{t}=2,297 ; \mathrm{p}<0.05)$, alt boyutlarında cinsiyete göre anlamlı farklılıklara rastlanmıştır. Öte yandan "zaman" ( $t=1,632$; $\mathrm{p}>0.05)$ ve "ilgi eksikliği" ( $\mathrm{t}=, 951 ; \mathrm{p}>0.05)$ alt boyutlarında cinsiyete göre anlamlı farklılıklar olmadığı görülmüştür.

Tablo 4. Araştırmada Serbest Zaman Engellerinin Yaş Değişkeni Açısından Karşılaştırılması

\begin{tabular}{lllllll}
\hline Alt Faktörler & Yaş & $\mathbf{n}$ & $\mathbf{x}$ & $\mathbf{s s}$ & $\mathbf{t}$ & $\mathbf{p}$ \\
\hline Ölçek Toplam & 14 & 14 & 82 & 2,9404 & 1,207 &, 307 \\
& 15 & 15 & 131 & 2,9529 & & \\
& 16 & 16 & 116 & 2,8669 & & \\
& 17 & 17 & 124 & 2,9001 & & \\
& Total & Total & 453 & 2,9142 & &, 156 \\
\hline Birey psikolojisi & 14 & 14 & 82 & 2,8049 & 1,752 & \\
& 15 & 15 & 131 & 2,9059 & & \\
& 16 & 16 & 116 & 2,8218 & & \\
& 17 & 17 & 124 & 2,7473 & &, 538 \\
\hline Bilgi eksikliği & Total & Total & 453 & 2,8227 & &, 725 \\
\hline
\end{tabular}


Önen L. (2021) Orta Ergenlik Dönemindeki Bireylerin Boş Zaman Faaliyetlerine Katılımlarına Engel

Olabilecek Unsurların Belirlenmesi.SPORTIVE, 4(2). 46-56

\begin{tabular}{|c|c|c|c|c|c|c|}
\hline & 15 & 15 & 131 & 3,1908 & & \\
\hline & 16 & 16 & 116 & 3,1063 & & \\
\hline & 17 & 17 & 124 & 3,1290 & & \\
\hline & Total & Total & 453 & 3,1567 & & \\
\hline \multirow[t]{5}{*}{ Tesis } & 14 & 14 & 82 & 3,0854 & \multirow[t]{5}{*}{1,253} & \multirow[t]{5}{*}{,290 } \\
\hline & 15 & 15 & 131 & 3,0967 & & \\
\hline & 16 & 16 & 116 & 2,9540 & & \\
\hline & 17 & 17 & 124 & 3,0484 & & \\
\hline & Total & Total & 453 & 3,0449 & & \\
\hline \multirow{5}{*}{$\begin{array}{l}\text { Arkadaş } \\
\text { eksikliği }\end{array}$} & 14 & 14 & 82 & 2,7398 & \multirow[t]{5}{*}{,239 } & \multirow[t]{5}{*}{,869 } \\
\hline & 15 & 15 & 131 & 2,6972 & & \\
\hline & 16 & 16 & 116 & 2,6580 & & \\
\hline & 17 & 17 & 124 & 2,6694 & & \\
\hline & Total & Total & 453 & 2,6873 & & \\
\hline \multirow[t]{5}{*}{ Zaman } & 14 & 14 & 82 & 2,9959 & \multirow[t]{5}{*}{,782 } & \multirow[t]{5}{*}{, 504} \\
\hline & 15 & 15 & 131 & 3,0382 & & \\
\hline & 16 & 16 & 116 & 2,9454 & & \\
\hline & 17 & 17 & 124 & 3,0511 & & \\
\hline & Total & Total & 453 & 3,0103 & & \\
\hline \multirow[t]{5}{*}{ İlgi eksikliği } & 14 & 14 & 82 & 2,8008 & \multirow[t]{5}{*}{,432 } & \multirow[t]{5}{*}{,730 } \\
\hline & 15 & 15 & 131 & 2,7888 & & \\
\hline & 16 & 16 & 116 & 2,7155 & & \\
\hline & 17 & 17 & 124 & 2,7554 & & \\
\hline & Total & Total & 453 & 2,7631 & & \\
\hline
\end{tabular}

Tablo 4`e göre yaş durumları açısından serbest zaman engellerinin alt boyutlar arası karşılaştırılması sonucunda anlamlı farklılıklar görülmemiştir. ( $p>0,05)$.

Tablo 5. Araştırmada Serbest Zaman Engellerinin Sınıf Değişkeni Açısından Karşılaştırılması

\begin{tabular}{llllllll}
\hline $\begin{array}{l}\text { Alt } \\
\text { Faktörler }\end{array}$ & Sınıf & $\mathbf{n}$ & $\mathbf{x}$ & $\mathbf{s s}$ & $\mathbf{t}$ & $\mathbf{p}$ & A.f \\
\hline Ölçek Toplam & 9.Sınıf & 204 & 2,9393 &, 36040 & 1,675 &, 172 & \\
& 10.Sınıf & 113 & 2,8677 &, 35660 & & & \\
& 11.Sınıf & 95 & 2,8807 &, 44951 & & & \\
& 12.Sınıf & 41 & 2,9946 &, 41328 & & & \\
& Total & $\mathbf{4 5 3}$ & $\mathbf{2 , 9 1 4 2}$ & $\mathbf{, 3 8 5 5 2}$ & & & \\
\hline Birey & 9.Sınıf & 204 & 2,8252 &, 58483 & 1,316 &, 268 \\
psikolojisi & 10.Sınıf & 113 & 2,8968 &, 53281 & & & \\
& 11.Sınıf & 95 & 2,7474 &, 49755 & & & \\
& 12.Sınıf & 41 & 2,7805 &, 62632 & & & \\
Bilgi eksikliği & Total & $\mathbf{4 5 3}$ & $\mathbf{2 , 8 2 2 7}$ & $\mathbf{, 5 5 9 3 5}$ & & & \\
& 9.Sınıf & 204 & 3,1912 &, 61450 & 1,171 &, 320 & \\
& 10.Sınıf & 113 & 3,1150 &, 55950 & & & \\
& 11.Sinıf & 95 & 3,0877 &, 72152 & & & \\
& 12.Sınıf & 41 & 3,2602 &, 48023 & & & \\
& Total & $\mathbf{4 5 3}$ & $\mathbf{3 , 1 5 6 7}$ & $\mathbf{6 1 5 4 5}$ & & & \\
\hline
\end{tabular}


Önen L. (2021) Orta Ergenlik Dönemindeki Bireylerin Boş Zaman Faaliyetlerine Katılımlarına Engel Olabilecek Unsurların Belirlenmesi.SPORTIVE, 4(2). 46-56

\begin{tabular}{|c|c|c|c|c|c|c|c|}
\hline \multirow[t]{5}{*}{ Tesis } & 9.Sinif & 204 & 3,1111 & ,55823 & \multirow[t]{5}{*}{3,432} & \multirow[t]{5}{*}{,017 } & \multirow[t]{5}{*}{$2-3$} \\
\hline & 10.Sinif & 113 & 2,9204 & 66409 & & & \\
\hline & 11.Sinif & 95 & 2,9860 & ,67707 & & & \\
\hline & 12.Sinuf & 41 & 3,1951 & 60081 & & & \\
\hline & Total & 453 & 3,0449 & ,62060 & & & \\
\hline \multirow{5}{*}{$\begin{array}{l}\text { Arkadaş } \\
\text { eksikliği }\end{array}$} & 9.Sinif & 204 & 2,7222 & ,68222 & \multirow[t]{5}{*}{1,145} & \multirow[t]{5}{*}{,330 } & \\
\hline & 10.Sinif & 113 & 2,5870 & ,71029 & & & \\
\hline & 11.Sinif & 95 & 2,6877 & ,75137 & & & \\
\hline & 12.Sinif & 41 & 2,7886 & ,89367 & & & \\
\hline & Total & 453 & 2,6873 & ,72534 & & & \\
\hline \multirow[t]{5}{*}{ Zaman } & 9.Sinif & 204 & 3,0016 & ,57924 & \multirow[t]{5}{*}{1,010} & \multirow[t]{5}{*}{,388 } & \\
\hline & 10.Sinif & 113 & 2,9705 & ,60677 & & & \\
\hline & 11.Sinif & 95 & 3,0140 &, 58126 & & & \\
\hline & 12.Sinif & 41 & 3,1545 & ,59674 & & & \\
\hline & Total & 453 & 3,0103 & ,58823 & & & \\
\hline \multirow[t]{5}{*}{ İlgi eksikliği } & 9.Sinif & 204 & 2,7843 & ,60674 & \multirow[t]{5}{*}{,329 } & \multirow[t]{5}{*}{,804 } & \\
\hline & 10.Sinif & 113 & 2,7168 &, 55317 & & & \\
\hline & 11.Sinif & 95 & 2,7614 & ,61437 & & & \\
\hline & 12.Sinif & 41 & 2,7886 & ,70220 & & & \\
\hline & Total & 453 & 2,7631 & ,60340 & & & \\
\hline
\end{tabular}

Tablo 5`e göre boş zaman engelleri ölçeği alt boyutlarının sınıf değişkenine göre analiz sonuçları incelendiğinde, "tesis" ( $\mathrm{t}=3,432 ; \mathrm{p}<0.05)$ alt boyutunda sınıf değişkenine göre 10 ve 11 . Sınıf öğrencileri arasında anlamlı farklılığa rastlanmıştır. Diğer alt boyutlarda ise anlamlı farklılıklara rastlanılmamıştır.

Tablo 6. Ölçeğe Ait Güvenilirlik Değerleri

\begin{tabular}{lll}
\hline Ölçek ve Alt Boyutları & item & $\begin{array}{l}\text { Cronbach } \\
\text { Alpha }\end{array}$ \\
\hline Ölçek Toplam & 18 &, 793 \\
Birey psikolojisi & 3 &, 531 \\
Bilgi eksikliği & 3 &, 618 \\
Tesis & 3 &, 748 \\
Arkadaş eksikliği & 3 &, 729 \\
Zaman & 3 &, 552 \\
Ilgi eksikliği & 3 &, 536 \\
\hline
\end{tabular}

Tablo 6'da araştırmaya ilişkin güvenilirlik değerleri, ,531 ile ,793 arasında değişkenlik göstermektedir. Ölçek toplamında güvenilir bir değer aldığı söylenebilir.

\section{TARTIŞMA ve SONUÇ}

$\mathrm{Bu}$ çalışmada, orta ergenlik dönemindeki bireylerin rekreasyonel etkinliklere katılımında oluşacak engellerin bazı bağımsız değişkenlere göre farklılaşıp farklılaşmadığı saptanmaya çalışılmıştır. Bu amaç doğrultusunda orta ergenlik dönemindeki bireylerin boş zaman engelleri alt boyutlarına göre sınıf düzeyi, cinsiyet ve yaş değişkenleri açısından farklılık olup olmadığına bakılmış ve bu farklılıkların hangi nedenden kaynaklandığı incelenmiştir. 
Yapılan analizler sonucunda serbest zaman engelleri ölçeği 6 alt boyut ([1] "zaman ve ilgi eksikliği", [2] "birey psikolojisi”, [3] "bilgi eksikliği”, [4] "ulaşım sorunu”, [5] "tesis yetersizliği” ve [6] "arkadaş eksikliği”) altında toplanmış ve demografik bilgiler arasındaki ilişkiler değerlendirilmiştir.

Orta ergenlik dönemindeki bireylerin rekreasyonel aktivitelere katılımina engel olan alt faktörlere ilişkin tutumlarının cinsiyet değişkenine göre yapılan t-testi sonuçlarına göre "arkadaş eksikliği" ( $\mathrm{t}=2,837 ; \mathrm{p}<0.05)$, "tesis" $(\mathrm{t}=2,120 ; \mathrm{p}<0.05)$, "bilgi eksikliği”" ( $\mathrm{t}=2,594 ; \mathrm{p}<0.05) \quad$ ve "birey psikolojisi" ( $\mathrm{t}=2,297 ; \mathrm{p}<0.05)$, alt boyutlarında cinsiyete göre anlamlı farklılıklar görülmüştür. T-testi sonuçlarına göre, "arkadaş eksikliği", "tesis", "bilgi eksikliği" ve "birey psikolojisi" alt boyutlarının kadın öğrencilerden kaynaklandığını göstermektedir. Bu çalışmaya benzer yapılmış çalışmalarda cinsiyetin boş zaman etkinliklerine katılımda anlamlı bir etkisi olduğu ve kadınların erkeklere oranla daha fazla engelle yüzleştiği sonucuna varılmıştır (Akt Ayhan, 2017; Jackson ve Henderson, 1995; Shaw, 1994). "Üniversite Öğrencilerinin Sportif ve Sportif Olmayan Rekreatif Etkinliklere Katılmalarına Engel Olabilecek Unsurların İncelenmesi” adlı yapılan çalışmada katılımcıların boş zaman engellerinin cinsiyetlere göre "bilgi eksikliği" ve "arkadaş eksikliği" alt boyutlarında anlamlı farklılıklar gösterdiği saptanmıştır (Ekinci vd., 2014). Öte yandan kamu personelleri üzerine yapılan bir çalışmada (Pala ve Dinç, 2013); üniversite öğrencileri üzerine yapılan bir çalışmada (Emir vd., 2012); gençler üzerine yapılan bir çalışmada (Özşaker, 2012); üniversite öğrencileri üzerine yapılan bir çalışmada (Demirel ve Demirel, 2009); cinsiyete göre "birey psikolojisi", "bilgi eksikliği”, ve "tesis yetersizliği" alt boyutlarında anlamlı farklılıklar olduğu yönünde benzerlikler görülmüştür $(p<0.05)$.

Orta ergenlik dönemindeki bireylerin yaş değişkeni ile boş zaman engelleri düzeyleri arasında istatistiki yönden anlamlı bir farklılığın olup olmadığını incelemek için tek yönlü varyans analizi (ANOVA) testi uygulandı. Yapılan analizlere bakıldığında, yaş değişkeni ile serbest zaman engellerinin karşlaştırılması neticesinde istatistiksel olarak anlamlı farklılıklar görülmemiştir. $(\mathrm{p}>0,05)$. İlgili literatür incelendiğinde, istatistiki yönden anlamlı farklılıklar görülmüş olup elde edilen sonuçlar bu çalışma bulgularına tezatlık göstermektedir. Paksoy ve diğerlerine (2016) göre, farklı yaş aralığındaki öğrenciler ile serbest zaman engelleri arasında anlamlı farklılıklar bulunmuştur (Paksoy vd., 2016). Yapılan bir diğer çalışmada ise yaş değişkeni ile boş zaman engelleri alt boyutlarında anlaml farklılıklar olduğu görülmüştür (Pala ve Dinç, 2013). Bulunan sonuçlar bu araştırmanın bulguları ile örtüşmemektedir. Bu duruma, araştırma grubunun bulunduğu konum ile sahip olduğu kültürel farklılıkların sebep olduğu düşünülmektedir.

Orta ergenlik dönemindeki bireylerin sınıf değişkeni ile boş zaman engelleri düzeyleri arasında istatistiksel yönden anlamlı bir fark olup olmadığını incelemek için tek yönlü varyans analizi (ANOVA) testi uygulandı. Boş zaman engelleri ölçeği 
alt boyutlarının sınıf değişkenine göre analiz sonuçları incelendiğinde, "Tesis" ( $\mathrm{t}=$ $3,432 ; \mathrm{p}<0.05)$ alt boyutunda sinıf değişkenine göre 10 ve 11 . Sinıf öğrencileri arasında anlamlı farklılı̆ga rastlanmıştır. Diğer alt boyutlarda ise istatiksel yönden anlamlı farklılıklara rastlanılmamıştır. Bu çalışmaya benzer olarak, lise öğrencileri üzerine yapılan bir çalışmada (Çavdar ve Yıldız, 2020), sınıf düzeyi ile "Tesis" ve "Arkadaş eksikliği" alt boyutlarında anlamlı farklılıklara ulaşıldığı saptanmış olup çalışmada elde edilen bulguları doğrular niteliktedir.

$\mathrm{Bu}$ çalışma neticesinde, orta ergenlik düzeyindeki bireylerin cinsiyet, ve sinıf düzeyleri arasında istatistiki yönden anlamlı farklılıklar bulunurken; yaş düzeyleri arasında istatistiki yönden anlamlı bir farklılık tespit edilmemiştir. Literatürde yer alan çalışmalar değerlendirildiğinde, kadınların erkeklere oranla daha fazla engellerle karşılaştığı, tesislerin yetersiz kaldığı, arkadaş eksikliği ile ilgi ve bilgi eksikliğinin ön planda olduğu ortaya çıkmıştır.

Bu çalışma, katılımcılarının sadece orta ergenlik düzeyindeki bireyler olmasından dolayı sınırlıdır. Bu sebeple yapılacak olan yeni çalışmaların daha geniş kapsamlı ve farklı gruplar üzerine yapılması yararlı olacaktır. Orta ergenlik dönemi bireyleri önündeki engelleri kaldırabilmek amacıyla; il milli eğitim müdürlüğü, yerel yönetimler, okullar, gençlik ve spor il müdürlüğü ve gençlik üzerine çalışan sivil toplum kuruluşları gibi kurum ve kuruluşlar ile ortak stratejiler geliştirilebilir ve bu işbirliği dahilinde tüm ergenlik dönemi bireylerinin ilgisini çekecek şekilde daha kapsamlı kültürel, sosyal ve sportif serbest zaman faaliyetleri düzenlenebilir.

Araştırmacıların Katkı Oranı Beyanı: Araştırma Dizaynı- Lukman ÖNEN; İstatistik analiz- Lukman ÖNEN; Makalenin hazırlanmas1- Lukman ÖNEN; Verilerin Toplanması- Lukman ÖNEN tarafından gerçekleştirilmiştir.

Çıkar Çatışması: Çalışma kapsamında herhangi bir kişisel ve finansal çıkar çatışması bulunmamaktadır.

\section{Etik Kurul İzni ile ilgili Bilgiler}

Kurul Adı: Necmettin Erbakan Üniversitesi Etik Kurulu

Tarih: 16/04/2021

Sayı/Karar No: 2021/248

\section{KAYNAKLAR}

Akçan Parlaz, E., Tekgül, N., Karademirci, E., \& Öngel, K. (2012). Ergenlik Dönemi: Fiziksel büyüme, psikolojik ve sosyal gelişim süreci. Turkish Family Physician, 3(4), 10-16.

Akkaşoğlu, S., \& Akyol, C. (2020). Gençlerin boş zamanlarında rekreasyon faaliyetlerine katılım engelleri üzerine bir araştırma (a research on the obstacles for participations in recreation activities of youth in leisure time). Journal of Tourism and Gastronomy Studies, 8(3), 20722089. https://doi.org/10.21325/jotags.2020.649

Akman, M., Tüzün, S., \& Ünalan, P. (2012). Adolesanlarda sağlıklı beslenme ve fiziksel aktivite 
Önen L. (2021) Orta Ergenlik Dönemindeki Bireylerin Boş Zaman Faaliyetlerine Katılımlarına Engel Olabilecek Unsurların Belirlenmesi.SPORTIVE, 4(2). 46-56

durumu. Nobel Medicus Journal, 8(1), 24-29.

Alexandris, K., \& Carroll, B. (1997). Demographic differences in the perception of constraints on recreational sport participation: Results from a study in Greece. Leisure Studies, 16(2), 107-125.

Ayhan, C. (2017). Aktif sporcularin rekreatif etkinliklere katılımlarına engel oluşturabilecek faktörlerin yaşam tatmini ve yaşam kalitesi üzerine etkisi. [Yüksek lisans tezi, Sakarya Üniversitesi Eğitim Bilimleri Enstitüsü].

Bakır, M. (1990). Rekreasyon ve turizm ilişkisinin turizm politikalarının oluşturulmasındaki önemi. [Yayımlanmamış doktora tezi, İstanbul Üniversitesi Sosyal Bilimler Enstitüsü].

Bulut, M., \& Koçak, F. (2016). Hazirlik öğrenïmï gören kadın üniversite öğrencilerïnin rekreatif etkïnliklere katilmalarini engelleyen faktörlerïn belïrlenmesi. Spor ve Performans Araştırmaları Dergisi, 7(2), 61-71. https://doi.org/10.17155/spd.85530

Çavdar, Ç., \& Yıldız, M. (2020). Lise öğrencilerinin rekreasyonel faaliyetlere eğilimleri ve katılımlarına engel olan faktörler. Beden Eğitimi ve Spor Bilimleri Dergisi, 14(3), 437-449. https://dergipark.org.tr/en/download/article-file/1061420

Demirel, M., \& Demirel, D. H. (2009). Üniversite öğrencilerinin rekreasyonel etkinliklere katılı mlarında engel oluşturabilecek faktörlerin belirlenmesi. Uluslararası İnsan Bilimleri Dergisi, $6(1), 838-846$.

Dinç, N., Güzel, P., \& Özbey, S. (2018). Rekreasyonel fiziksel aktiviteler ile yaşam kalitesi arasındaki ilişki. Manisa Celal Bayar Üniversitesi Sağllk Bilimleri Enstitüsü Dergisi, 5(4), 181-186.

Ekinci, N. E., Kalkavan, A., Gündüz, B., \& Üstün, Ü. D. (2014). Üniversite öğrencilerinin sportif ve sportif olmayan rekreatif etkinliklere katılmalarına engel olabilecek unsurların incelenmesi. Sportif Bakış: Spor ve Eğitim Bilimleri Dergisi, 1(1), 1-13.

Emir, E., Öncü, E., \& Gürbüz, B. (2012). Rekreatif etkinliklere katılımın önündeki engellerin belirlenmesi: Üniversite öğrencileri örneği. Journal of Human Sciences, 14(4), 2012.

George, D., \& Mallery, M. (2010). SPSS for Windows step by step: A simple guide and reference, 17.0 update (10a ed.).

Gürbüz, B., Öncü, E., \& Emir, E. (2020). Boş Zaman Engelleri Ölçeği: Kısa Formunun Yapı Geçerliğinin Test Edilmesi. Spor ve Performans Araştırmaları Dergisi, 11(2), 120-131. https://doi.org/10.17155/omuspd.602660

Dünya Sağlık Örgütü (WHO), Orientation programme on adolescent health for health-care providers. https://www.who.int/maternal_child_adolescent/documents/pdfs/9241591269_op_handout.pdf (erişim: 10/07/2021).

Kaas, E. T. (2016). Üniversite öğrencilerinde serbest zaman engelleriyle baş etme, yaşam tatmini ve vücut algısının incelenmesi. Eğitim ve Öğretim Araştırmaları Dergisi, 5(2), 10-19.

Orel, F., \& Yavuz, C. M. (2003). Rekreasyonel turizmde müşteri potansiyelinin belirlenmesine yönelik bir pilot çalışma. Çukurova Üniversitesi Sosyal Bilimler Enstitüsü Dergisi, 11(11), 61-76. http://dergipark.ulakbim.gov.tr/cusosbil/article/view/5000000965

Özşaker, M. (2012). Gençlerin serbest zaman aktivitelerine katılamama nedenleri üzerine bir inceleme. Selçuk Üniversitesi Beden Eğitimi ve Spor Bilim Dergisi, 14(1), 126-131.

Paksoy, M., Çalik, F., Yaşartürk, F., \& Çimen, K. (2016). Abdullah Gül Üniversitesi öğrencilerinin rekreasyon etkinliklerine katılıminı etkileyen faktörler. International Journal of Sport Culture and Science, 4(1), 39-50.

Pala, F., \& Dinç, S. C. (2013). Kamu kurumlarında görev yapan personelin serbest zaman etkinliklerine katılımını engelleyen faktörlerin belirlenmesi. 2. Rekreasyon Araştırmaları Kongresi, Aydın, 632-637.

Temir, Ö., \& Gürbüz, B. (2012). Rekreasyonel aktivitelere katılımın önündeki engellerin incelenmesi. 1. Rekreasyon Araştırmaları Kongresi, Antalya, 1040-1045.

Türkay, O., Korkutata, A., Şengül, S., \& Solmaz, S. A. (2015). Animasyon hizmetlerinin rekabet gücüne katkısı: Otel işletmelerinde katılımcı ve pazar yönlü örgüt kültürünün etkileri bağlamında bir araştırma. Bartın Üniversitesi İ.I.B.F. Dergisi, 6(12), 79-102.

Uzun, A., \& Boyalı, E. (2020). Ergenlik Dönemleri ve Spor, İ̧̧inde Çocuk ve Eğzersiz (1. ed,. ss. 123141), Ankara: Gece Kitaplığ

Yavaş, C. Ö. G. (2012). Orta ve geç ergenlik dönemindeki ergenlerde tutum ve davranıs farklılıkları. Ankara Üniversitesi Sosyal Bilimler Dergisi, $3(2), \quad 113-138$. https://doi.org/10.1501/sbeder_0000000048 